Attila Végh, Zoltán Rajnai:

\title{
DEVELOPMENT DIRECTIONS \\ OF MOBILE SYSTEMS TO HELP HUMAN RESOURCES
}

\author{
DOI: $10.35926 /$ HDR.2019.1-2.2
}

\begin{abstract}
Electronic information systems used by interior and national emergency organizations are based on the same functional components, but even within an organization, specific entities can be equipped with different types of devices from different manufacturers. Apart from the fact that today the management of increasingly complex systems requires serious expertise, it is also complicated with the diversity of system components so in their operation it is hard to become proficient and well-skilled. The attention of the operator becomes divided, so it is not entirely focused on their task. The topicality of the matter is the growing number of security developments. The purpose of my publication is to explore the tools and user aspects - with emphasis on user overload - related to these systems.
\end{abstract}

KEYWORDS: digital communication, mobile systems, NVR, TETRA

\section{INTRODUCTION}

Seminars and exhibitions dealing with interior and national security issues present interesting novelties and systems with useful new features year after year. This process is deliberate, Europe's security situation has prompted European Union leaders and defense industry players to change and continuously improve. One of the results is that EU leaders approved the Rome Declaration on 25 March 2017. In this statement, EU leaders have committed themselves, to strengthen the common security and defense policy in cooperation with NATO on the one hand, and to support a more competitive and integrated defense industry on the other.'

The result of this process is that the emergency organizations can continuously modernize and replace their equipment that has been used up due to the lack of financial resources. However, this puts a lot of pressure on system operators: they have to learn the management of new technologies parallel with their standard workload, and they may have to manage multiple technical solutions simultanously with the same activity. There are several reasons for this: from the technical side, the continuous development of the manufacturers, and from the financial side, the purchases of the replacement equipment are not based on the manu-

\footnotetext{
1 “A Bizottság vitafórumot rendez az európai védelem jövőjéről”. European Comission. 24 May 2017. http://europa.eu/rapid/press-release IP-17-1427 hu.htm, Accessed on 23 May 2018.
} 
facturer or the type of the equipment, but on the better offer price in a competitive tendering procedure.

Operating the system components distracts the attention of an already overloaded staff from the management of their tasks. This is especially true for drivers of vehicles equipped with complex systems. ${ }^{2}$ From Border Police's mobile thermal imaging car to modern police cars, vehicles are all equipped with sophisticated IT systems that require drivers to handle these components at a high skill level.

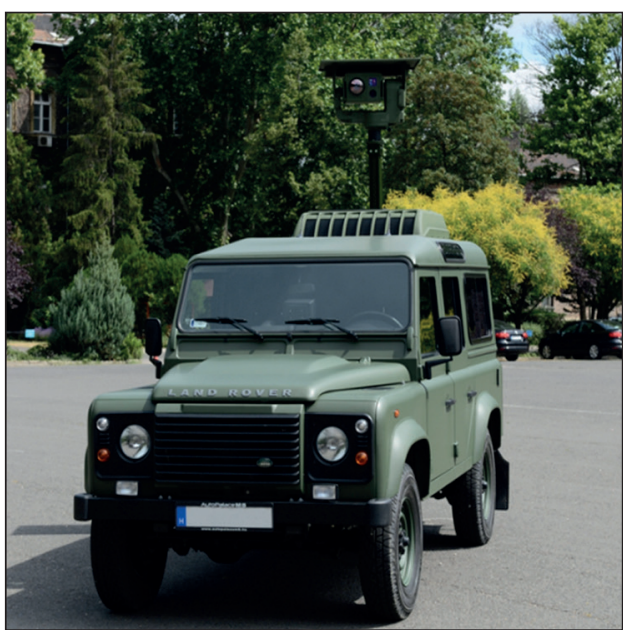

Figure 1: Mobile thermal imaging $\mathrm{car}^{3}$

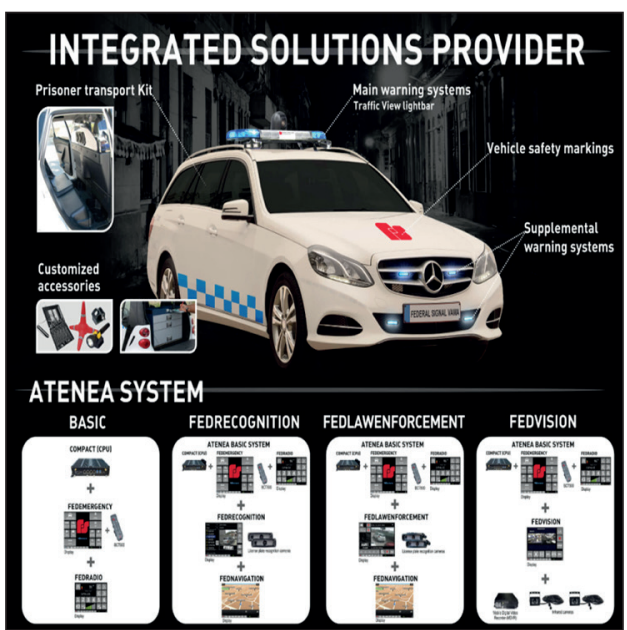

Figure 2: Integrated solution from Federal Signal ${ }^{4}$

Several manufacturers have recognized the above-mentioned problem, and for ease of use, integrated the separated systems into a common interface. These integration packs include the manufacturers' own product line and other products from a narrow range of suppliers, so full implementation for older purchases cannot be achived with these systems.

For a complete implementation, a general-purpose integration platform should be developed that is capable of handling devices with the same functionality in one system, providing the same interface.

\section{DETERMINATION OF DEVELOPMENT GOALS AND DIRECTIONS}

In order to determine the purpose and exact directions of the niche development, the type of equipment used by user organizations, the use case should be assessed and we need to know user opinions, needs, and helpful comments on how to use the tools.

\footnotetext{
2 James, S. M. "Distracted driving impairs patrol officer driving performance". Policing: An International Journal of Police Strategies and Management 38/3. 2015. 505-516. DOI: $10.0 .3 .248 /$ i.tig.2007.12.002

3 “Újabb hőkamerás fejlesztések". 9 July 2014. http://www.police.hu/hirek-es-informaciok/legfrissebb-hireink/ hatarrendeszet/ujabb-hokameras-fejlesztesek, Accessed on 23 May 2018.

4 “ATENA System". https://www.fedsigvama.com/en/product/atenea-system/, Accessed on 23 May 2018.
} 
In the rest of the study, I present a survey of the technical equipment used by emergency organizations, as well as a survey of users' direct opinions. For the survey I chose empirical research from the special methods, we used a questionnaire method, and we made interviews. $^{5}$

\section{VOICE COMMUNICATION DEVICES}

The purpose of speech communication devices is to achieve immediate, reliable group communication between the driver and the dispatcher - who controls their activity.

For the purposes of the study, two modes of communication are distinguished:

- point to point communication

- point to multipoint communication

A typical example of point-to-point communication is when the two parties can talk to each other in full duplex (they can listen and talk at the same time).

In a point to multipoint communication on the other had, we always distingwish a transmitting party who initiates the call by pressing the PTT (Push to Talk) button and opens the channel to all the other devices in that particular group that can receive the transmitted content. Once the transmission is ended any of the group's participants can initiate a response call.

The benefit of group communication - PTT communication - is that the information for a group member is shared immediately. For a particular event, all members of the geographically dispersed intervention staff (belonging to the same speech group) are fully provided with the event information, are also aware of the instructions the other staff has received, therefore the individual is able to carry out its own task in full transparency of the entire activity.

Of course, PTT-based voice transmission is the main function of the equipment, but modern devices can also be used in additional communication modes:

- private call initiation;

- sending short text messages (all user, status);

- sending telemetry informations (control inputs, outputs, status polling);

- data communications (sending GPS positions, low rate data communication).

The above is true for modern digital systems. Analog devices are only suitable for their main function, using minimal signaling system, or some type is suitable for data transmission at a limited speed.

TETRA $^{6}$ digital trunked radio standard was defined in the 1990s. The purpose of the standard is to create a spectrum efficient system by defining 4 logical speech channels on a $25 \mathrm{kHz}$ wide radio channel, and to create a scalable trunk infrastructure for a large number of users. TETRA can provide single, multi-site and even nationwide coverage. The system got in focus when the Schengen Border Cooperation was defined, which required a cross-border communication system between the cooperating organizations. In that time the cooperation between standardization organizations, manufacturers, users of international organizations was exemplary.

5 Berek L., Rajnai Z. and Berek L. A tudományos kutatás folyamata és módszerei. Budapest: Óbudai Egyetem Bánki Donát Gépész és Biztonságtechnikai Mérnöki Kar, 2018. 36-39.

6 TETRA - Terrestrial Trunked Radio - European standard for trunked radio system 
The TETRA system in Europe is typically used by emergency organizations. In addition, there are civil organizations that are very similar to professional establishments with regard to their fleets, their equipment and should use the same system to facilitate cooperation.

Nowadays for civil organizations (such as public police and outgoing cars of civil security services, in Hungary), $\mathrm{DMR}^{7}$ system is most commonly used for voice communication. Of course, it is reliable, even tens of years have not completely worn out such analogue systems, but fading of compatible DMR systems into the background, which ensures a continuous transition, is expected as the equipment breaks.

On other continents, systems with a similar set of services, and the way they are used, could be interpreted as the same as the TETRA standard. In the United States, a system called $\mathrm{P} 25^{8}$ was constructed while in China the $\mathrm{PDT}^{9}$ system was introduced. These systems do not differ in their integration from the systems used in Europe.

The use of a new technology started in critical communications, LTE ${ }^{10}$, which had already proven its capabilities in mobile data communication, when allowing high data rates to be used. The solution used in this system is called PTT over the LTE. Its widespread availability is expected in the near future.

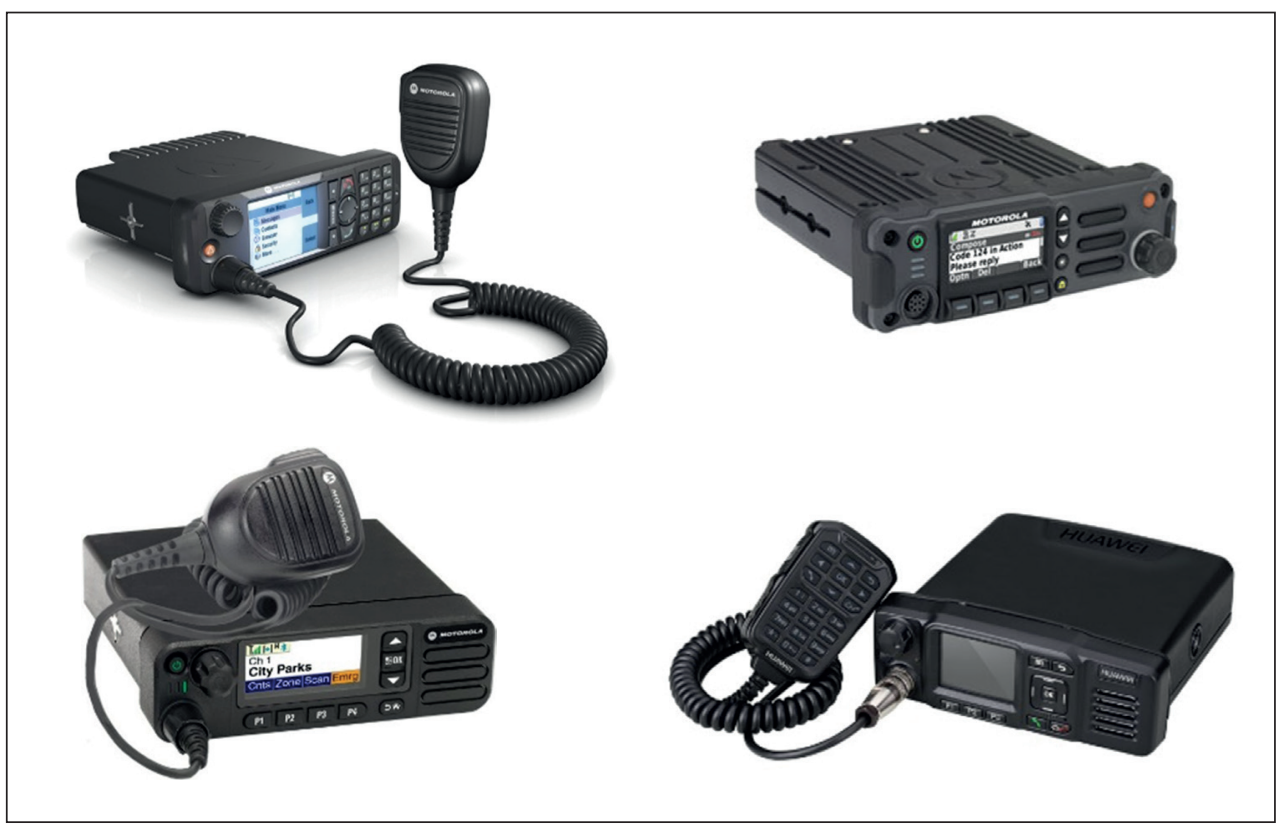

Figure 3: Mobile versions of TETRA, P25, DMR, and LTE radios ${ }^{11}$

\footnotetext{
${ }^{7}$ DMR - Digital Mobile Radio - standard defined by ETSI for frequency efficient evolution of analogue radio system

${ }^{8}$ P25 - Project 25, standards for public safety organizations in North America, replacement for analog radios

9 PDT - Professional or Police Digital Trunking - open standard for trunked police radio system in China

${ }^{10}$ LTE - Long-Term Evolution, a standard for wireless broadband communication for mobile or data terminals

11 “TETRA Radio Solutions". MOTOROLA Solutions. https://www.motorolasolutions.com/en_xu/products/tetra. html, Accessed on 23 January 2018.; "EV 750 Vehicle Radio". Huawei. http://e.huawei.com/en/products/wireless/elte-trunking/trunking-terminal/ev750, Accessed on 23 January 2018.
} 
After defining the devices, we need to identify the integration interface where these devices become suitable not for their own system environment or for access or control functions via their own interfaces. With an overview of the leading manufacturers of equipment, we can see that the USB ${ }^{12}$ or RS232 serial port is defined as the device integration interface.

We can state that the TETRA equipment may possibly be integrated with the RS232 ${ }^{13}$ port, while the DMR equipment can be integrated on the USB interface with a NDIS ${ }^{14}$ driver.

The driver supplied by the manufacturer supports the environment of the windows operating system, so it is advisable to consider this aspect for development. ${ }^{15}$

\section{LIGHT BARS AND SIRENS}

The purpose of the distinctive sound and light signals is to signal the approach of a special vehicle to other participants in traffic on the road, and their obligation to give priority. This ensures that the travel time is significantly reduced in a specific traffic situation.

In accordance with Decree 12/2007. (III. 13.) of the Hungarian Ministry of Justice and Law Enforcement, distinctive light signals are blue or blue-red, the device blinks at different speeds, or a sound signal when the siren is changing pitch.

Light signals are mostly used in roof-mounted design, which ensures that it is detectable from a long distance. If needed, additional flashing lights are used beside the light bars for better visibility. Regardless of their manufacturers, it can be stated that modern light signals use efficient, low power LED technology of high brightness. However, it is not possible to ignore the old flashing devices or the rotating mirror visual warning signals.

The light signals have two modes of control. One is that each function of these devices can be activated separately on a dedicated interface, and the other is to receive information from the device interface via a communication bus to activate the functions.

The use of the communication bus is not yet widespread, it is expected to be more widely adopted in the future. During the development, it is advisable to prepare for it, but the main direction of the system should be used by the parallel communication.

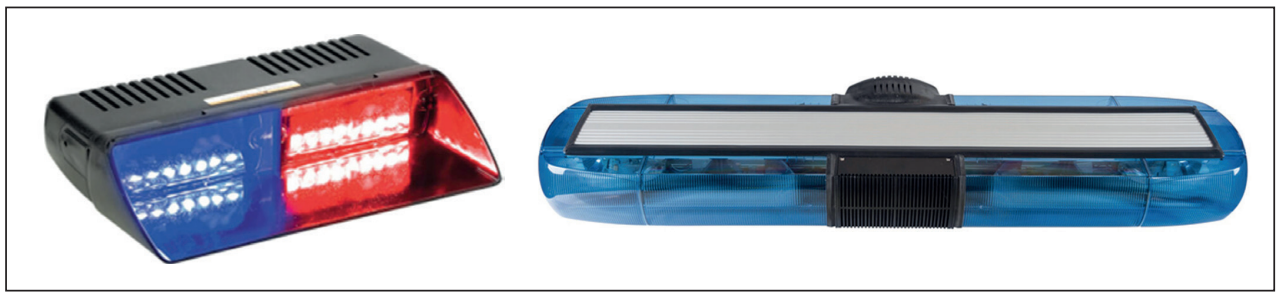

Figure 4: Modern light bars $^{16}$

${ }^{12}$ USB - Universal Serial Bus is an industry standard for a communication platform between computers, peripheral devices and other computers

${ }^{13}$ RS232 - Recommended Standard 232, an industry standard for serial communication platform between computers, peripheral devices and other computers

${ }^{14}$ NDIS - Network Driver Interface Specification abstracts lower-level drivers that manage hardware from upper-level drivers, such as network transports

${ }^{15}$ Farkas T. and Prisznyák Sz. "Kormányzati célú infokommunikációs hálózatok: A rendészeti szervek infokommunikációs rendszere”. Hadtudományi Szemle 10/4. 2017. 583-596.

http://epa.oszk.hu/02400/02463/00037/pdf/EPA02463 hadtudomanyi szemle 2017 04 583-596.pdf

16 "Phoenix Series". https://www.fedsigvama.com/en/product/serie-phoenix/, Accessed on 23 January 2018. 
In the case of audible signals, the siren control unit determines the siren sounds. This unit is usually integrated with the amplifier. Controlling the sounds can also be handled from a control wire, or in the new units, the CAN control bus ${ }^{17}$ can be used similarly to the light signals. ${ }^{18}$

\section{ON-BOARD VIDEO RECORDERS}

The purpose of on-board video recording equipment is on the one hand, to capture the traffic conditions of the vehicle or video record police actions, and on the other hand, visual or in-vehicle speech record the behavior of passengers and forced passengers in the vehicle.

Simple on-board cameras fulfil only commercial demands, for instance, a clear recording of traffic situations, and they are able save information on their own internal memory or an SD card. Such devices are equipped with accelerometer, GPS, motion detector, and can manage the recordings via their own applications - if Wi-Fi or bluetooth connection is available.

It is easy to see that these tools are not suitable for integration into the planned system. The functional features of professional devices specifically designed for installation in the vehicle are the same as those of modern professional imaging equipment, however, their whole design and cable interface surfaces are designed for a more demanding environment (continuous shaking, temperature changes).

Closed circuit, so the cameras are connected directly to the recording equipment, the information is only available to the authorized person.

Some manufacturers (for example, of the Dahua devices in our study) also provide software components for the development of the devices to integrate their equipment to a special vhehice. ${ }^{19}$

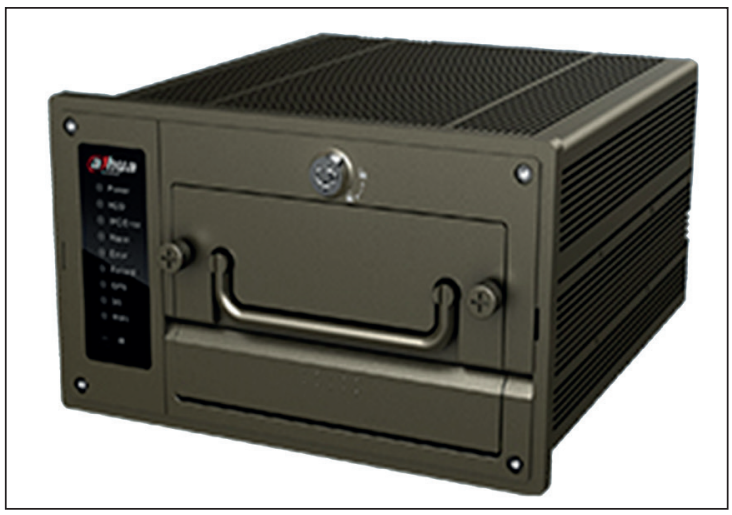

Figure 5: On-board NVR ${ }^{20}$

${ }^{17}$ CAN bus - Controller Area Network is a comunication standard designed for the microcontrollers, computer mainly in vehicle application.

18 Rusz D. “A megkülönböztető jelzések jogszabályi háttere és aktualitása”. Hadmérnök 10/4. 2015. 43-55. http://hadmernok.hu/153_04_ruszd.pdf

${ }_{19}$ Berek L., Berek T. and Berek L. Személy- és vagyonbiztonság. Budapest, Óbudai Egyetem Bánki Donát Gépész és Biztonságtechnikai Mérnöki Kar, 2016. 51-66.

${ }^{20}$ NVR - a computer with a special program that records and processes IP camera streams. "Mobile NVR: NVR0404MF". Dahua Technology. http://au.dahuasecurity.com/au/products/nvr0404mf-11951.html, Accessed on 23 January 2018. 


\section{AUTOMATIC VEHICLE LOCATION}

The Global Positioning System - the GPS - is a widespread, reliable system that can determine the current position of the vehicle, or, by forwarding this position, you can immediately inform the dispatch center. ${ }^{21}$

Positioning should be the basis for integration. Due to the widespread use of the system, several devices have been listed in which this module is integrated:

- devices for modern digital PTT communication (TETRA, DMR, LTE)

- mobile NVR with optional card

- mobile PC with optional card.

\section{ON-BOARD COMPUTERS}

The purpose of the on-board computer is to assemble the components to incorporate it into the development, control through its hardware unit, and running the software components to be developed, visual display of system states.

The computer must handle the components that are installed in the vehicle listed above, therefore, they must have matching interfaces, communication ports.

The computer has to be designed for special needs, so it must be protected against extreme temperature and environmental influences.

It is best to design a touch screen interface for the computer, due to the problem of keyboard and mouse placement. ${ }^{22}$

\section{DEVICES TO BE INTEGRATED IN THE FUTURE ACCORDING TO THE TREND}

According to this trend, the basic equipment of future patrol cars will not change in the next 10 years, however, the interfaces of the devices are expected to be converted to digital communication.

A couple of professional materials forecast the direction that car manufacturers make "ready" patrol cars - with factory-fitted equipment. However, in this case, the manufacturers of professional tools determine the main supplier direction, since the development of the target devices and the professionals are found in these companies.

\footnotetext{
${ }^{21}$ RUDOLF Á. “GPS rendszer müködése és alkalmazása a biztonságtechnikában”. Hadmérnök 7/1. 2012. 40-47. http://hadmernok.hu/2012 1 rudolf.pdf

22 "Mobile Computing Solutions". Nexcom. http://www.nexcom.com/Products/mobile-computing-solutions, Accessed on 27 May 2018.
} 


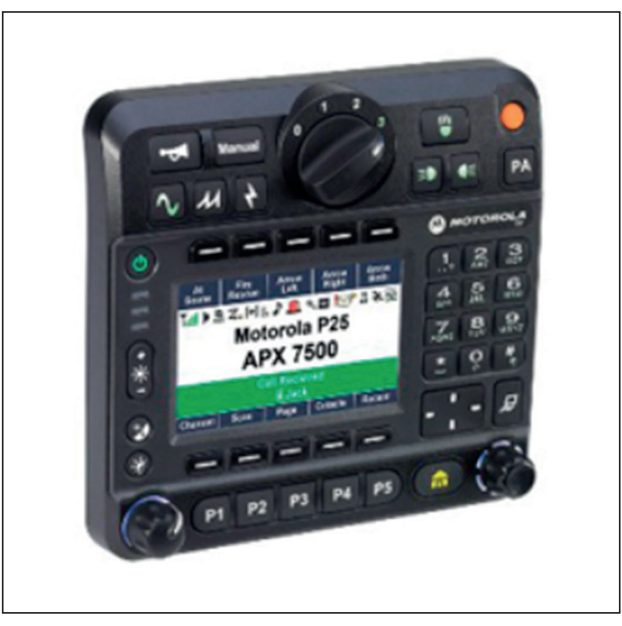

Figure 6: Motorola Integrated Control Panel ${ }^{23}$

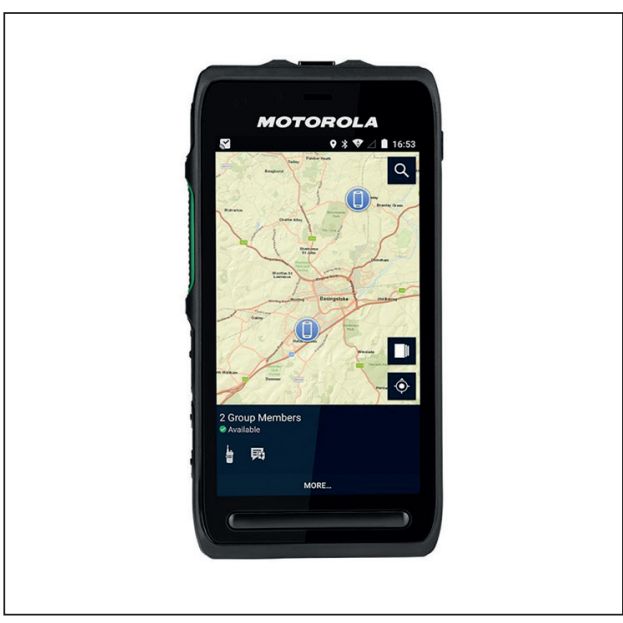

Figure 7: Motorola Mission Critical LTE device $^{24}$

Convergence is expected in the field of voice and video communications, its signs can also be found in the new government-oriented LTE equipment. The devices come onto the market with a touchscreen display, a camera, and a dedicated PTT button, suitable for communicating specifically on LTE systems for government purposes. There will also be a future for the deployment of vehicle-mounted devices through Voice over LTE applications like Mission Critical PTT. ${ }^{25}$

\section{SURVEY RESEARCH}

In order to achieve the research goals, I have divided the available human resources into four research groups. The four research teams surveyed the leaders of the Hungarian emergency organizations with a survey questionnaire, visited experts in these systems in Budapest and in all county headquarters in the country. We interviewed the Police, the Counter Terrorism Centre, the National Directorate General for Disaster Management, the National Ambulance Service and the National Tax and Customs Administration staff, about their experience and opinion of the digital systems in use.

Before completing the questionnaire compiled by us, we were informed during a personal interview about the mobile data systems installed in the organizations' service vehicles and their experience in using it, and local forms of protection against security threats to IT systems. After the interview, we had the questionnaire completed on a voluntary basis and it was done without exception.

\footnotetext{
23 “APXтм 7500 Multi-Band P25 Mobile Radio”. Motorola Solutions. https://www.motorolasolutions.com/en_us/ products/two-way-radios/project-25-radios/discontinued/apx-7500.html\#tabproductinfo, Accessed on 27 May 2018.

24 “LEX L11 Mission Critical LTE Device”. MOTOROLA Solutions. https://www.motorolasolutions.com/en us/ products/lte-broadband-systems/volte.html\#tabproductinfo, Accessed on 27 May 2015.

25 "VoLTE (Voice over LTE)". MOTOROLA Solutions. https://www.motorolasolutions.com/en_us/products/ 1te-user-devices/lex111.html\#tabproductinfo, Accessed on 27 May 2015.
} 
The questionnaires were processed one by one, organizations were visited by research teams, and the answers to questions $1-8$, and the number of responses from interviewees to the given question were analysed. The survey was answered by 60 people.

\section{QUESTIONS OF THE SURVEY QUESTIONNAIRE}

1. What kind of tools are available in the vehicles of the emergency organizations? on-board computer

voice communication device (TETRA, DMR, etc.)

$\square$ light bars and sirens

$\square$ on-board video recorders

$\square$ other devices (please list them)

The respondents were marked without exception, so they are in the patrol vehicles, and they have to use it on every deployment - the voice communication devices (in this case the TETRA radio), $91.7 \%$ the lightbars and sirens, while $83.3 \%$ the on-board computers, $61.7 \%$ the on-board cameras and $10 \%$ other, in-vehicle systems. They listed to the other devices on-board terminals (called "IPT" in the vehicles of the National Ambulance Service), smartphones, if necessary, public address loudspeakers, and mobile reflectors. In addition, some police authorities listed bulletproof vests in the vehicle that became necessary during deployments, or the use of roadblocks, or occasional use of images from public surveillance cameras.

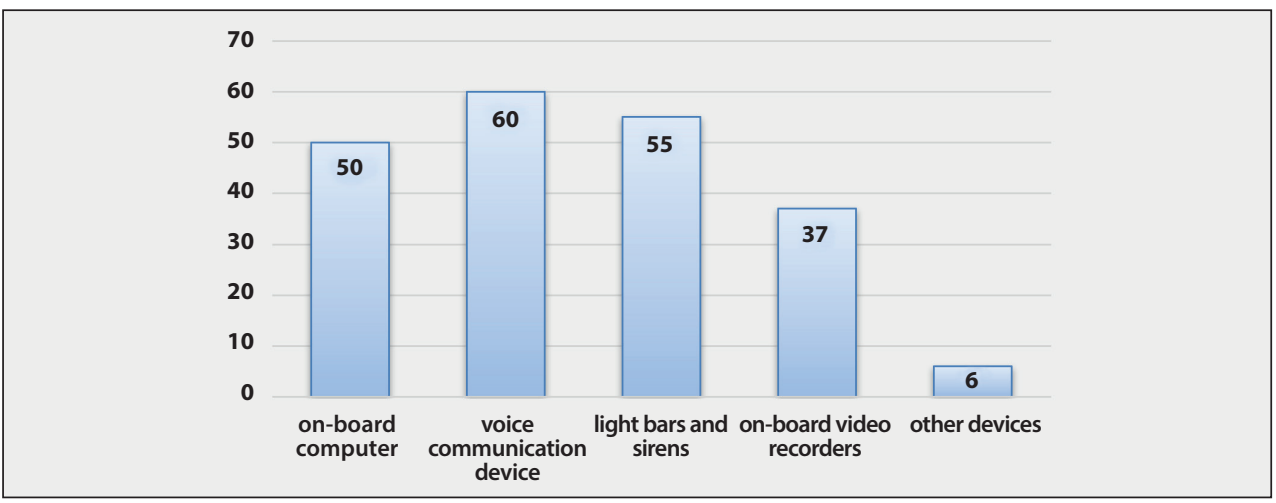

Figure 8: Number of answers to question 1 (edited by the publisher)

2. How does it impact the distraction of driving the paralell use of the devices above during deployment? (Please indicate one possible answer)
highly
a little
not at all

$66.7 \%$ of respondents stated that operating in-vehicle technical devices is only a little distracting, $23.3 \%$ finds this workflow very straining, and $10 \%$ do not feel the burden of handling the tools at all. 


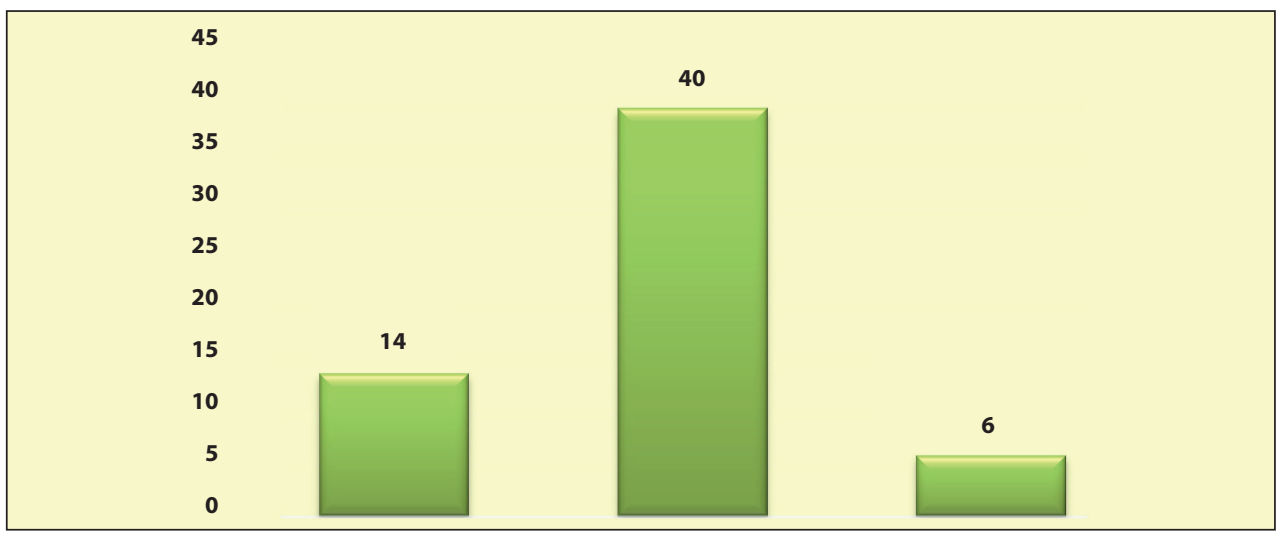

Figure 9: Number of answers to question 2 (edited by the publisher)

3. Your organization will need in the future (Please indicate all the possible answers)

$\square$ easy implementation of local communication

$\square$ easy communication with central organizations

$\square$ easy access to the database of local and central organizations

$\square$ high speed data access at variable locations

$\square$ communication options between different communication networks and devices (eg: laptop, applications used by mobile devices, etc.)

$76.7 \%$ of the experienced staff of the emergency organizations completing the questionnaire think that their organization would need high-speed data access. $60 \%$ lack communication tools and capabilities between different communication networks and devices, 46.7\% consider it important to have easy access to the database of local and central organizations, while $28.3 \%$ vote to preparing easy to communicate with central organizations and only $20 \%$ think that the simple implementation of local communication could help their work the most.

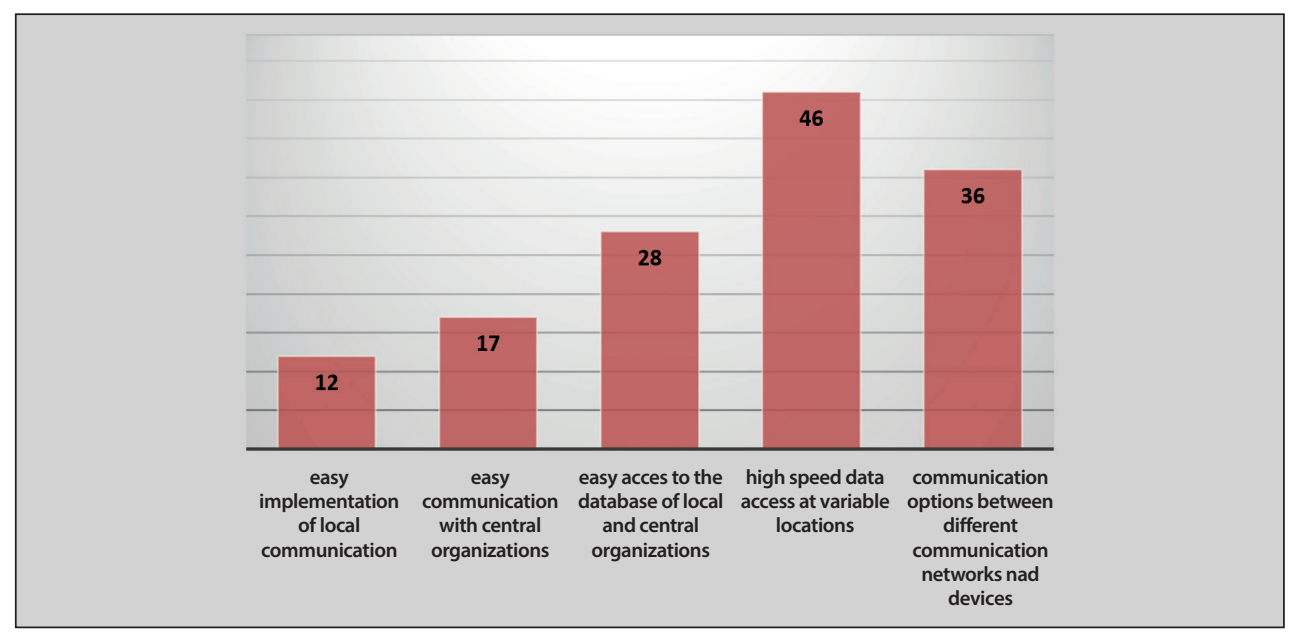

Figure 10: Number of answers to question 3 (edited by the publisher) 
4. Does your organization use mobile video solution? (Please indicate all the possible answers)

$\square$ we use a mobile camera system

$\square$ we use a camera system worn by the end user (body worn camera, camera mounted on a helmet, etc.)

$\square$ we use video analytics software

$\square$ we do not use a mobile camera system

$65 \%$ of the surveyed said, that there is a camera system in the service vehicles of their organization and is used in their work. During the interview, we came to the conclusion that this was basically true for police vehicles.

$35 \%$ of the respondents indicated in the questionnaire that they do not use video capture solution, $25 \%$ is the end user who uses a body camera or a helmet mounted camera. They also belong to the police. Only $10 \%$ of the interviewees use video analysis software during their work.

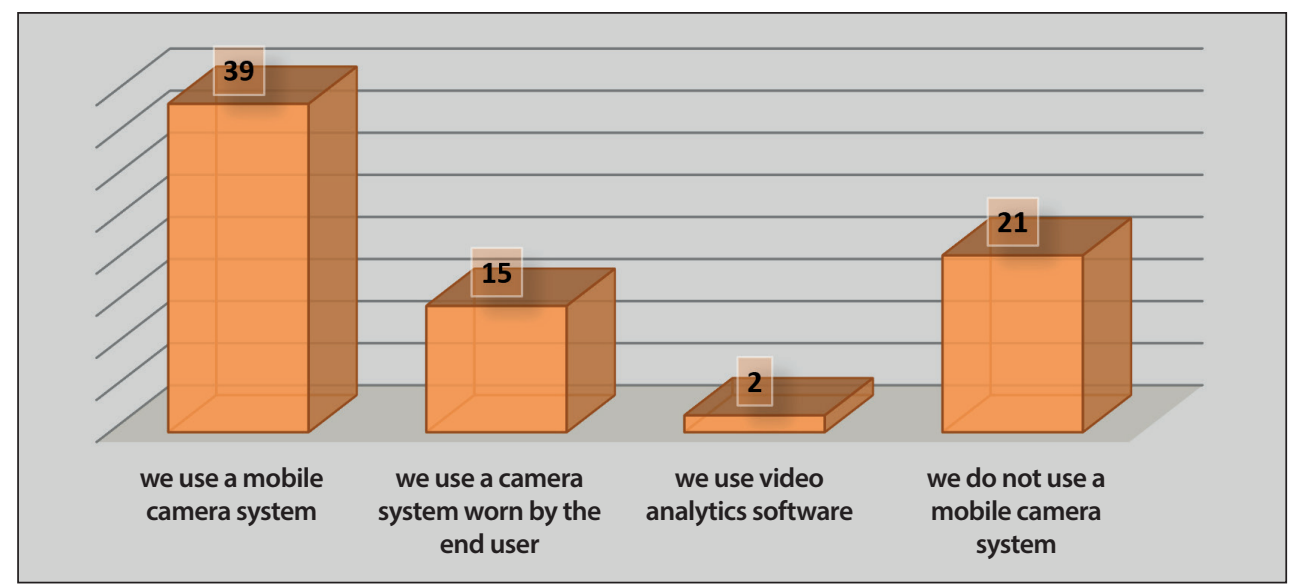

Figure 11: Number of answers to question 4 (edited by the publisher)

5. How important is real-time data access to your emergency organization? (Please indicate one possible answer)

$\square$ critical - data access has higher priority than voice communication

$\square$ very important - data access has the same priority as voice communication

$\square$ important - data access is important when there is no voice communication

$\square$ less important - data access can wait until colleagues return to the station

From 31 emergency organization staffs 60 respondents interviewed during the survey said that the real-time data access is very important, it has same priotrity as voice communication. 22 said that real-time acces is only important when there is no voice communication; 5 people believe that real-time data access has higher priority than voice communication.

Just two participants thought that data access could wait until colleagues return to their place of service, so no data is required to be queried at the site during the deployment. 


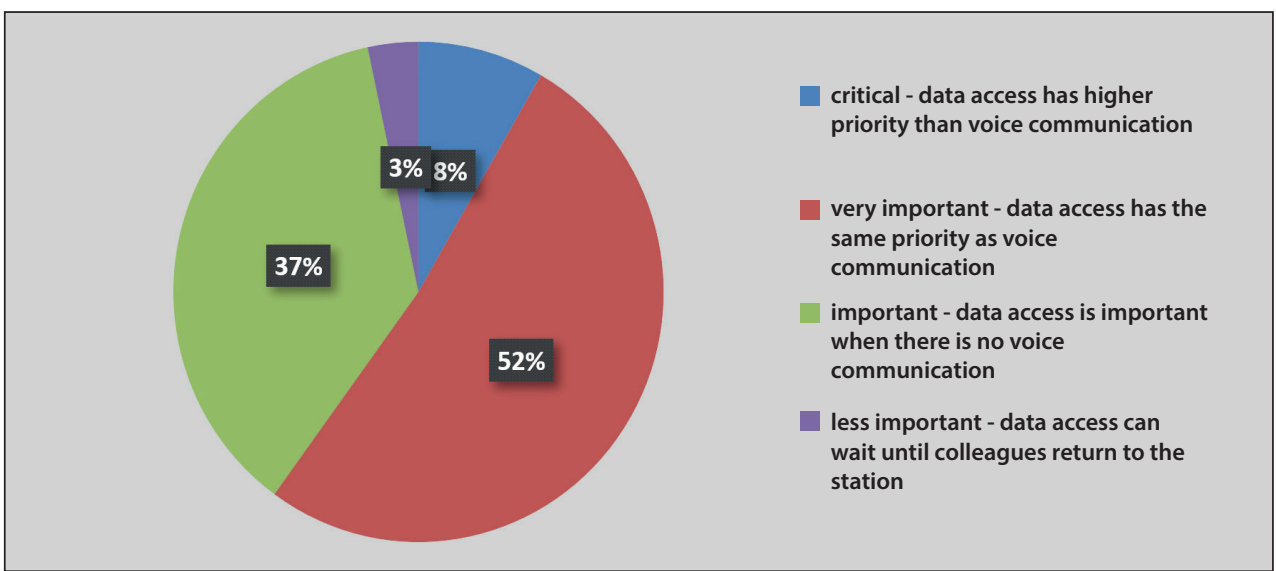

Figure 12: The proportion of the answers to question 5 (edited by the publisher)

6. Does your emergency organisation need data access during deployment? (Please indicate one possible answer)
$\square$ always
$\square$ sometimes
$\square$ never

$55 \%$ of respondents think that data access is required every time during deployment, the remaining $45 \%$ believe that this is necessary only sometimes.

(The question is related to the previous one, therefore there is some doubt to the answer given by those two persons to question 5, stating that data access can wait until colleagues return to the station.)

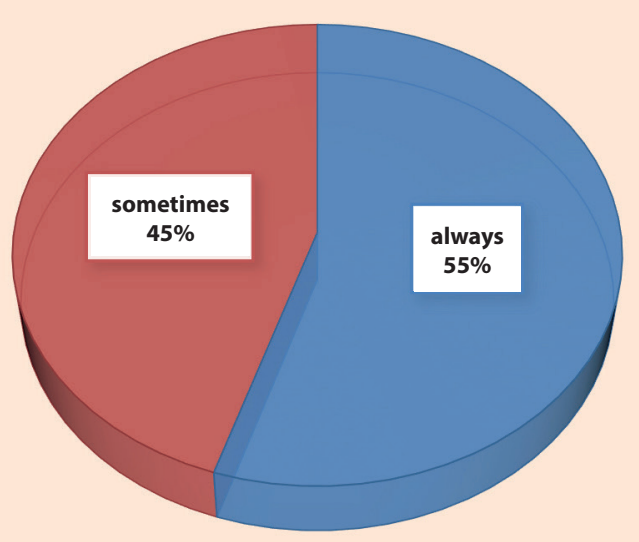

Figure 13: Proportion of responses to question 6 (edited by the publisher) 
7. What tools are used to access the data? (Please indicate all the possible answers)

$\square$ an on-board $p c$

$\square$ portable devices (please list them)

Based on $80 \%$ of the answes, data are accessed by a computer installed in the vehicle, $51.6 \%$ use portable device (TETRA, tablet, notebook, laptop or smartphone) to access data. Both replies could be marked, so there is an overlap in the number of responses.

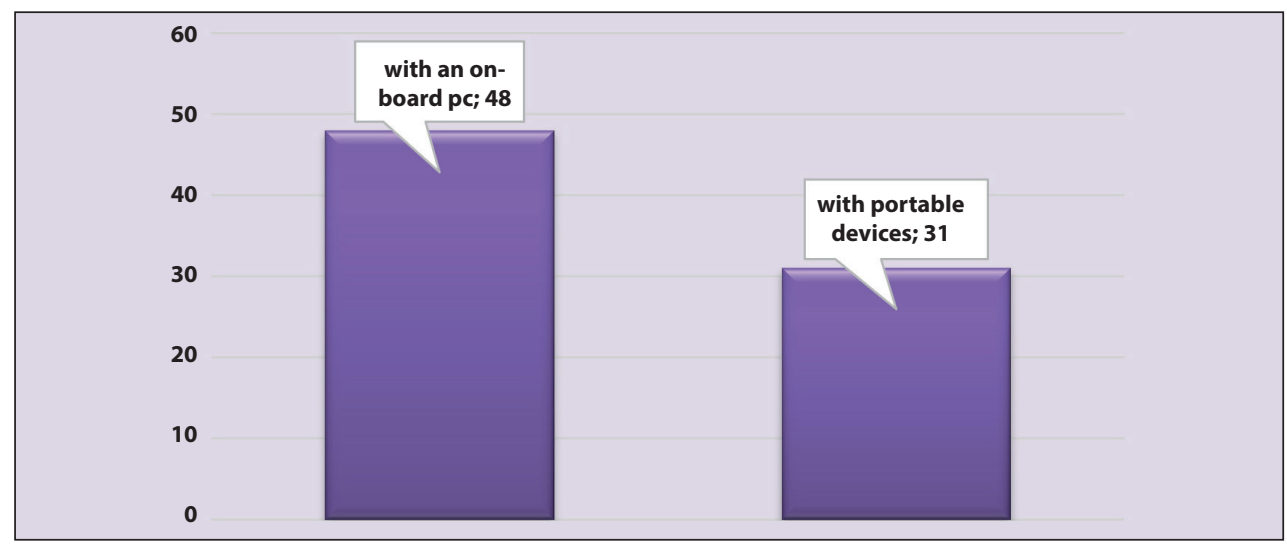

Figure 14: Number of answers to question 7 (edited by the publisher)

8. How is their organization protected against the security threat to their IT system? (Please indicate all the possible answers)

$\square$ with the staff training

$\square$ with daily safety audit

$\square$ with antivirus software

$\square$ using spam and phishing filters

$\square$ with data encryption

$\square$ with data access control

$\square$ with firewall

$\square$ I have no information

According to the information provided by the respondents the segment examined is basically and primarily ( $85-85 \%)$ protected with firewall and antivirus software. This is followed by - with an almost equal percentage - the limitation and regulation of user data access (68\%), education on IT security (63\%), and use of spam and phishing filters (57\%).

Data encryption, as a protection method was indicated on the fifth place, $48 \%$.

The last form of defense of the imaginary ranking, daily security audits are rarely used by law enforcement and emergency services, only $12 \%$ of the respondents' answers mentions it. 


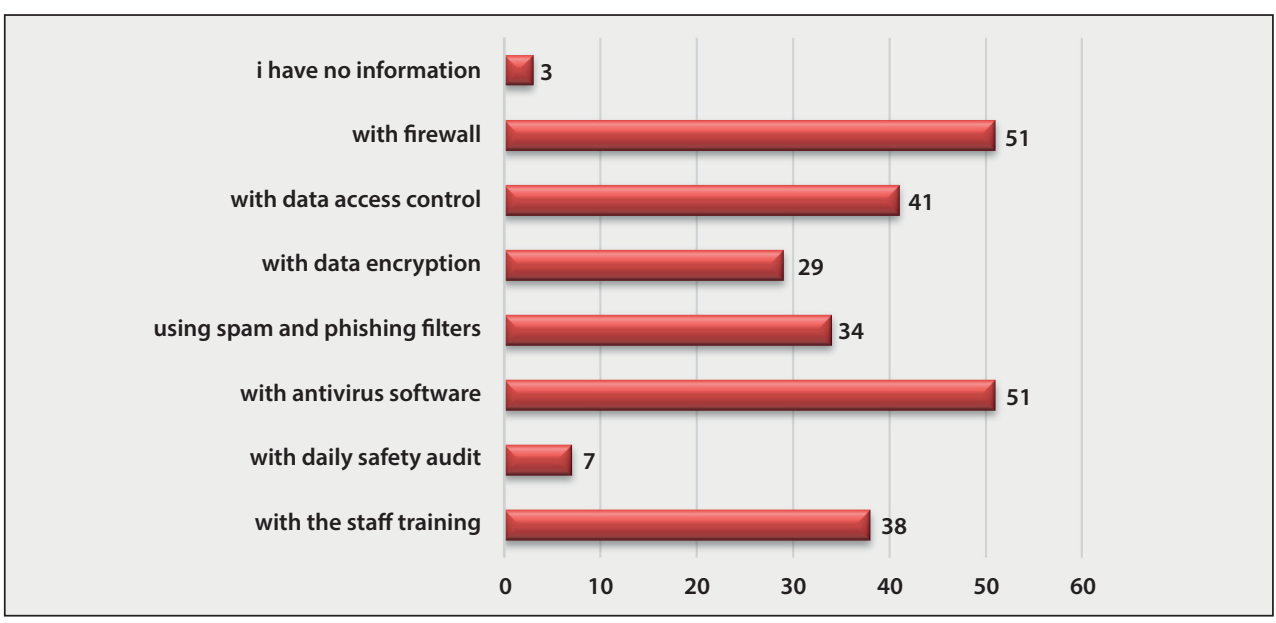

Figure 15: Number of answers to question 8 (edited by the publisher)

\section{PERIPHERALS TO BE INTEGRATED IN THE PRESENT AND THE FUTURE, ACCORDING TO THE TREND}

Vehicles used by the enforcement or emergency organizations are basically not equipped, and we can declare that assets, according to their basic features, minimally differ from each other.

The conclusion of the above is that it is enough to find this common set, for which the system to be developed has to be prepared. According to the previous results it can be stated that the focus of development has to be on the following devices:

- voice communication devices (TETRA, DMR or analogue PTT based devices)

- light bars and sirens

- on-board video recording devices

- automatic vehicle location

- on-board computers

\section{CONCLUSION}

Complex systems used by domestic law enforcement and emergency organizations include digital or analog components of nearly the same purpose and operation. These increasingly sophisticated systems need to be handled by the operators in addition to their basic task. Beyond the listed tools, using additional tools during deployments is needed (body worn camera, bulletproof vest, mobile reflector, stinger, paper-based documentation, other law enforcement tools, etc.), which requires extra attention and focus from the employee.

During my research, I made sure that the use of mobile systems installed in a vehicle is particularly dangerous while driving. The solutions provided by the main manufacturers only manage the problem at the level of integration and do not provide a solution to the distracting components. 
The results described in my publications can form the basis for the design and development of systems, which do not present additional workload on the user but effectively help their work.

\section{BIBLIOGRAPHY}

“APXтм 7500 Multi-Band P25 Mobile Radio”. Motorola Solutions. https://www.motorolasolutions. com/en_us/products/two-way-radios/project-25-radios/discontinued/apx-7500.html\#tabproductinfo, Accessed on 27 May 2018.

"ATENA System." https://www.fedsigvama.com/en/product/atenea-system/, Accessed on 23 May 2018.

Berek L., Berek T. and Berek L. Személy- és vagyonbiztonság. Budapest, Óbudai Egyetem Bánki Donát Gépész és Biztonságtechnikai Mérnöki Kar, 2016.

Berek L., Rajnai Z. and Berek L. A tudományos kutatás folyamata és módszerei. Budapest: Óbudai Egyetem Bánki Donát Gépész és Biztonságtechnikai Mérnöki Kar, 2018.

“A Bizottság vitafórumot rendez az európai védelem jövőjéről”. European Comission. 24 May 2017. http://europa.eu/rapid/press-release_IP-17-1427 hu.htm, Accessed on 23 May 2018.

"EV 750 Vehicle Radio". Huawei. http://e.huawei.com/en/products/wireless/elte-trunking/trunking-terminal/ev750, Accessed on 23 January 2018.

Farkas T. and Prisznyák Sz. "Kormányzati célú infokommunikációs hálózatok: A rendészeti szervek infokommunikációs rendszer". Hadtudományi Szemle 10/4. 2017. 583-596. http://epa.oszk. hu/02400/02463/00037/pdf/EPA02463 hadtudomanyi_szemle_2017 04_583-596.pdf

James, S. M. "Distracted driving impairs patrol officer driving performance". Policing: An International Journal of Police Strategies and Management 38/3. 2015. 505-516.

DOI: 10.1108/PIJPSM-03-2015-0030

"LEX L11 Mission Critical LTE Device". MOTOROLA Solutions. https://www.motorolasolutions. com/en us/products/lte-user-devices/lexl11.html\#tabproductinfo, Accessed on 27 May 2015.

"Mobile Computing Solutions". Nexcom. http://www.nexcom.com/Products/mobile-computing-solutions, Accessed on 27 May 2018.

“Mobile NVR: NVR0404MF”. Dahua Technology. http://au.dahuasecurity.com/au/products/nvr0404mf-11951.html, Accessed on 23 January 2018.

"Phoenix Series". https://www.fedsigvama.com/en/product/serie-phoenix/, Accessed on 23 January 2018.

RUDOLF Á. “GPS rendszer müködése és alkalmazása a biztonságtechnikában”. Hadmérnök 7/1. 2012. 40-47. http://hadmernok.hu/2012_1_rudolf.pdf

Rusz D. “A megkülönböztető jelzések jogszabályi háttere és aktualitása”. Hadmérnök 10/4. 2015. 43-55. http://hadmernok.hu/153 04 ruszd.pdf

“TETRA Radio Solutions”. MOTOROLA Solutions. https://www.motorolasolutions.com/en_xu/products/tetra.html, Accessed on 23 January 2018.

"Újabb hőkamerás fejlesztések". 9 July 2014. http://www.police.hu/hirek-es-informaciok/legfrissebb-hireink/hatarrendeszet/ujabb-hokameras-fejlesztesek, Accessed on 23 May 2018.

"VoLTE (Voice over LTE)". MOTOROLA Solutions. https://www.motorolasolutions.com/en us/products/lte-broadband-systems/volte.html\#tabproductinfo, Accessed on 27 May 2015. 